\title{
Short-term variability in primary productivity during a wind-driven diatom bloom in the Gulf of Eilat (Aqaba)
}

\author{
David Iluz $^{1, *}$, Gal Dishon ${ }^{1}$, Elisa Capuzzo ${ }^{2}$, Efrat Meeder ${ }^{3}$, Rosa Astoreca ${ }^{4}$, \\ Vivian Montecino ${ }^{5}$, Petr Znachor ${ }^{6}$, Dilek Ediger ${ }^{7}$, John Marra ${ }^{8}$
}

${ }^{1}$ The Mina \& Everard Goodman Faculty of Life Sciences, and The Department of Geography and Environment, Bar-Ilan University, Ramat-Gan 52900, Israel

${ }^{2}$ School of Life Sciences, Napier University, Edinburgh, UK

${ }^{3}$ Interuniversity Institute for Marine Sciences, Eilat, and the Institute of Earth Sciences, The Hebrew University of Jerusalem, Jerusalem, Israel

${ }^{4}$ Ecologie des Systèmes Aquatiques, Faculté des Sciences, Université Libre de Bruxelles, Belgium

${ }^{5}$ Departamento de Ciencias Ecológicas, Facultad de Ciencias, Universidad de Chile, Santiago, Chile

${ }^{6}$ Laboratory of Phytoplankton Ecology, Institute of Hydrobiology, Biology Centre ASCR, Czech Republic

${ }^{7}$ Chemistry and Environment Institute, Gebze-Kocaeli, Turkey

${ }^{8}$ Brooklyn College of the City University of New York, Brooklyn, New York, USA

\begin{abstract}
In the northern Gulf of Eilat (Aqaba), sharp increases in the biomass of diatoms and rates of primary production occurred in April 2008. Within $24 \mathrm{~h}$, diatom abundance rose from $8 \times 10^{3}$ to $228 \times 10^{3}$ cells l$^{-1}$, and photosynthetic rates concomitantly doubled from 15 to $35 \mathrm{\mu g} \mathrm{C}^{-1} \mathrm{~d}^{-1}$. Water transparency declined, as indicated by the vertical diffusion attenuation coefficient $K_{\mathrm{d}}$ for photosynthetically active radiation (PAR), which increased from 0.076 to $0.090 \mathrm{~m}^{-1}$ and decreased the euphotic depth from 60 to $45 \mathrm{~m}$. During this time, a significant increase in silica deposition by the diatoms was also detected. We attribute the mentioned changes in environmental characteristics to wind-generated surface currents. Strong winds (up to $10 \mathrm{~m} \mathrm{~s}^{-1}$ ) during the measurements enriched the surface layers with unusually high nutrient concentrations within $<1 \mathrm{~d}$. Hence, primary production rates were observed at a relatively eutrophic nearshore station (MP) and pelagic station $\left(\mathrm{A}_{1}, 10 \mathrm{~km}\right.$ towards the center of the Gulf). They were compared with rates measured on the subsequent day. Values measured were twice as high as those at the pelagic station during the previous calm day. Routine monitoring programs with monthly or semi-weekly sampling are thus likely to miss brief but significant injections of nutrients, leading to the underestimation of seasonal and annual primary production. Our results demonstrate the impacts of transient events on the function and annual yield of aquatic ecosystems.
\end{abstract}

KEY WORDS: Primary production - Wind speed - Upwelling - Phytoplankton - Diatom blooms · Phytoplankton absorption

\section{INTRODUCTION}

During the 8th International Workshop of the Group on Aquatic Primary productivity (GAP) that took place at the Interuniversity Institute in Eilat (northern Red Sea, Israel), concomitant measurements of primary productivity were conducted in accordance with the philosophy and practice of GAP (Bar Zeev et al. 2009, this Special Issue). Here we describe an unexpected event that occurred while measuring planktonic primary productivity in the Gulf of Eilat (Aquaba), and which exposes potential underestimation resulting 
from the current routine practices of primary productivity monitoring.

Spatial and temporal distributions of primary production (PP) are consistent with limitations by light, nutrients, and temperature (Field et al. 1998). Nitrogen (N) limitation characterizes large areas of the world's oceanic, coastal, and estuarine waters (Dugdale 1967, Ryther \& Dunstan 1971, Codispoti 1989, Mackey et al. 2006), and the supply rate of biologically available $\mathrm{N}$ to these waters is a key control of PP and the resultant trophic state (Ryther \& Dunstan 1971, Eppley \& Peterson 1979, D'Elia et al. 1986, Nixon 1986, Tyrrell 1999, Chen et al. 2008).

While nutrient limitation of PP in the ocean has traditionally been attributed to $\mathrm{N}$, iron $(\mathrm{Fe})$ availability has more recently been found to be important (Chase et al. 2006, Chen et al. 2008), and phosphorus (P) has been suggested as the ultimate limiting nutrient over geological timescales (Redfield 1958, Follmi 1996, Tyrrell 1999, Mackey et al. 2006, 2007). The major source of $P$ in the ocean is the weathering of minerals on land and their subsequent introduction into the ocean by fluvial and aeolian transport (Filippelli \& Delaney 1996, Benitez-Nelson 2000, Chen et al. 2008). Because there is no $\mathrm{P}$ input process analogous to $\mathrm{N}$ fixation, marine productivity over geological timescales is considered to be a function of the supply rate of $\mathrm{P}$ from continental weathering and the rate at which $\mathrm{P}$ is recycled in the ocean (Scanlan \& Wilson 1999, Mackey et al. 2007).

There are a few events that can significantly increase oceanic PP. Hans (1997) found that atmospheric deposition (AD) contributes from 300 to $>1000 \mathrm{mg} \mathrm{N} \mathrm{m}^{-2} \mathrm{yr}^{-1}$ to coastal waters in the biologically available forms $\mathrm{NO}_{\mathrm{x}}{ }^{-}, \mathrm{NH}_{3} / \mathrm{NH}_{4}{ }^{+}$, and dissolved organic $\mathrm{N}_{\text {; }}$ and groundwater (GW) can jointly account for 20 to $>50 \%$ of total exogenous or 'new' $\mathrm{N}$ loading and may uniquely mediate coastal eutrophication by bypassing estuarine filters of terrigenous $\mathrm{N}$ inputs. Trace metal enrichment (e.g. Fe) in AD and GW may interact synergistically with $\mathrm{N}$ to stimulate coastal production. In deep (>200 m) oceanic regions away from land masses, much of the PP is dependent on regenerated ammonium derived from organic matter mineralization. Exceptions include production supported by $\mathrm{N}$ fixation or $\mathrm{NO}_{3}$ from upwelled deep water, both of which are considered new $\mathrm{N}$ sources. Coastal and estuarine environments are heavily influenced by new $\mathrm{N}$, which is supplied either naturally by weathering of minerals, decomposition, lightning, and geothermal emissions, or anthropogenically (Hans 1997).

Increasing quantities of atmospheric anthropogenic fixed $\mathrm{N}$ entering the open ocean could account for up to $1 / 3$ of the ocean's external (non-recycled) $\mathrm{N}$ supply and up to $\sim 3 \%$ of the annual new marine biological

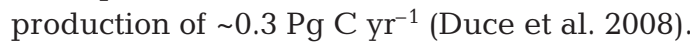

In the Gulf of Eilat, aerosol-borne trace element deposition has an impact on the surface water chemistry (Chen et al. (2008) and may thus affect PP in the surface water by supplying important macro- and micronutrients or, possibly, high levels of toxic elements. The study by Chen et al. (2008) shows that, even in an area dominated by mineral dust deposition and surrounded by deserts, anthropogenic air emissions may make a significant contribution to the levels of various trace elements such as $\mathrm{Cu}_{1} \mathrm{Cd}, \mathrm{Ni}, \mathrm{Zn}$, and $\mathrm{P}$. The estimated residence time of a few years for most trace elements underscores the importance of atmospheric fluxes to the Gulf ecosystem and the episodic nature of such deposition events demonstrates that these may have a large impact.

Other phenomena that can change nutrient availability include the El Niño-Southern Oscillation (ENSO) and cyclones. Between September 1997 and August 2000, biospheric net PP varied by 6 Pg C yr ${ }^{-1}$

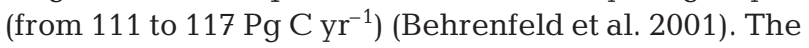
passage of cyclone Wasa in December 1991 led to increases in biomass and PP that were related to nutrient enrichment either from terrestrial runoff or resuspended sediments. The predominance of diatoms during cyclones seems to be a general pattern that can be related to their higher growth rates compared to other phytoplankters (Delesalle et al. 1993).

Episodic eddy-driven upwelling may supply a significant fraction of the nutrients required to sustain PP of the subtropical ocean. Mode-water eddies can generate extraordinary diatom biomass and PP at depth relative to the time series near Bermuda. These blooms are sustained by eddy-wind interactions that amplify the eddy-induced upwelling (McGillicuddy et al. 2007).

The Gulf of Eilat, which is an arm of the Red Sea, is an oligotrophic region with predictable seasonal cycles in macronutrient concentrations and phytoplankton community structure that are similar to other oligotrophic areas of the world's oceans, such as the open ocean gyres. Changes in the dominance of different phytoplankton groups occur as the deep mixing conditions in winter relax, and stratification intensifies beginning in early spring and continuing through summer. Specifically, a bloom of eukaryotic nanophytoplankton characteristic of the winter-summer transition is replaced by a summer community dominated by picophytoplankton $(<5 \mu \mathrm{m})$, of which Prochlorococcus and Synechococcus are the most numerous (Lindell \& Post 1995).

Atmospheric inputs of other nutrients gradually increase the likelihood of P limitation in the Gulf (Chen et al. 2007). Simultaneously, these atmospheric inputs provide an important source of seawater-soluble iron (Chase et al. 2006), which appears to remain in excess of that required for microbial growth throughout the 
year (Chen et al. 2007). During summer and fall, stratified surface waters are depleted of nutrients and picophytoplankton populations comprise the majority of cells (80 and $88 \%$, respectively). In winter, surface nutrient concentrations are higher and larger phytoplankton are more abundant (63\%) (Mackey et al. 2007).

The aim of the present study was to describe a winddriven transient high primary productivity event in the Gulf of Eilat that was associated with a diatom bloom. The mechanism by which winds brought about the phytoplankton response is shown, and the implications of such dramatic spikes for estimates and models of PP are discussed.

\section{MATERIALS AND METHODS}

Observations were performed during the GAP Workshop held on 30 March to 6 April 2008 at the Interuniversity Institute of Marine Sciences in Eilat. In situ measurements and water sampling were carried out on 1 April 2008 at the following 3 stations: Stn $A_{1}$, located $\sim 10 \mathrm{~km}$ southeast of the northern shore of the Gulf of Eilat along its meridional axis at $29^{\circ} 28^{\prime} \mathrm{N}$, $34^{\circ} 55^{\prime} \mathrm{E}$, with a bottom depth of $\sim 700 \mathrm{~m}$; Stn OS (open sea) $\left(29^{\circ} 29^{\prime} \mathrm{N}, 034^{\circ} 55^{\prime} \mathrm{E}\right)$, located in the middle of the Gulf opposite the IUI (Interuniversity Institute), with $400 \mathrm{~m}$ bottom depth; and Stn MP (Military Port) $\left(29^{\circ} 32^{\prime} \mathrm{N}, 034^{\circ} 57^{\prime} \mathrm{E}\right)$, located at the northern shore $100 \mathrm{~m}$ from the coast, with $30 \mathrm{~m}$ bottom depth (Fig. 1). Depth, temperature, salinity, and fluorescence were measured with a CTD-19 (Sea-Bird Electronics) and an in situ fluorometer (WetStar, WetLabs). Water samples were obtained with a rosette system of samplers from discrete depths of $1,20,40,60,80$, and $100 \mathrm{~m}$, and subsamples were taken from these depths for the measurement of PP. Laboratory analysis of the water samples comprised analyses of phytoplankton community structure, pigment absorption spectra, and heterotrophic bacterial count.

Light measurements. The underwater light field was measured using a standard high-resolution profiling reflectance radiometer (Biospherical PRR-800), and both downwelling $\left(E_{\mathrm{d}}\right)$ and upwelling irradiance $\left(L_{\mathrm{u}}\right)$ were recorded at 18 wavelengths $(305,313,320,340,395$, 443, 465, 490, 520, 560, 589, 665, 683, 694, 710, 765, 780, and $875 \mathrm{~nm}$ ) as well as $E_{\mathrm{dz}} \mathrm{PAR}$ (photosynthetic available radiation) (400-700 nm) and $L_{\mathrm{uz}} \mathrm{Chl}$ (natural fluorescence). The PRR-800 also included internal sensors for temperature, detector-array temperature, inclination (roll/pitch), and depth. An onboard computer recorded the data during the casts. Light casts were done from the surface to $100 \mathrm{~m}$ depth. The diffusion attenuation coefficient $\left(K_{\mathrm{d}}\right)$ and euphotic zone depth $\left(Z_{\text {eu }}\right)$ were calculated from the $E_{\mathrm{d}}$ PAR profiles. $E_{\mathrm{d}}$ was determined at $1 \mathrm{~m}$ intervals, and $K_{\mathrm{d}}$ was calculated over $5 \mathrm{~m}$ intervals, using PROFILER software as:

$$
K_{\mathrm{d}}(\lambda)=\frac{\ln \left(E_{\mathrm{d}}(\lambda)_{\left(z_{1}\right)} / E_{\mathrm{d}}(\lambda)_{\left(z_{2}\right)}\right)}{\left(Z_{2}-Z_{1}\right)}
$$

where $E_{\mathrm{d}}$ is the downwelling irradiance (in $\mu \mathrm{W} \mathrm{cm}^{-2}$ $\mathrm{nm}^{-1}$ for any specific wavelength $\lambda$ or $\mu$ mol photon $\mathrm{cm}^{-2} \mathrm{~s}^{-1}$ for PAR), $Z_{1}$ and $Z_{2}$ are 2 measured depths (m) and $K_{\mathrm{d}}$ is the attenuation coefficient $\left(\mathrm{m}^{-1}\right)$ calculated for the depth interval $Z_{2}-Z_{1}$. The euphotic depth $\left(Z_{\text {eu }}\right)$
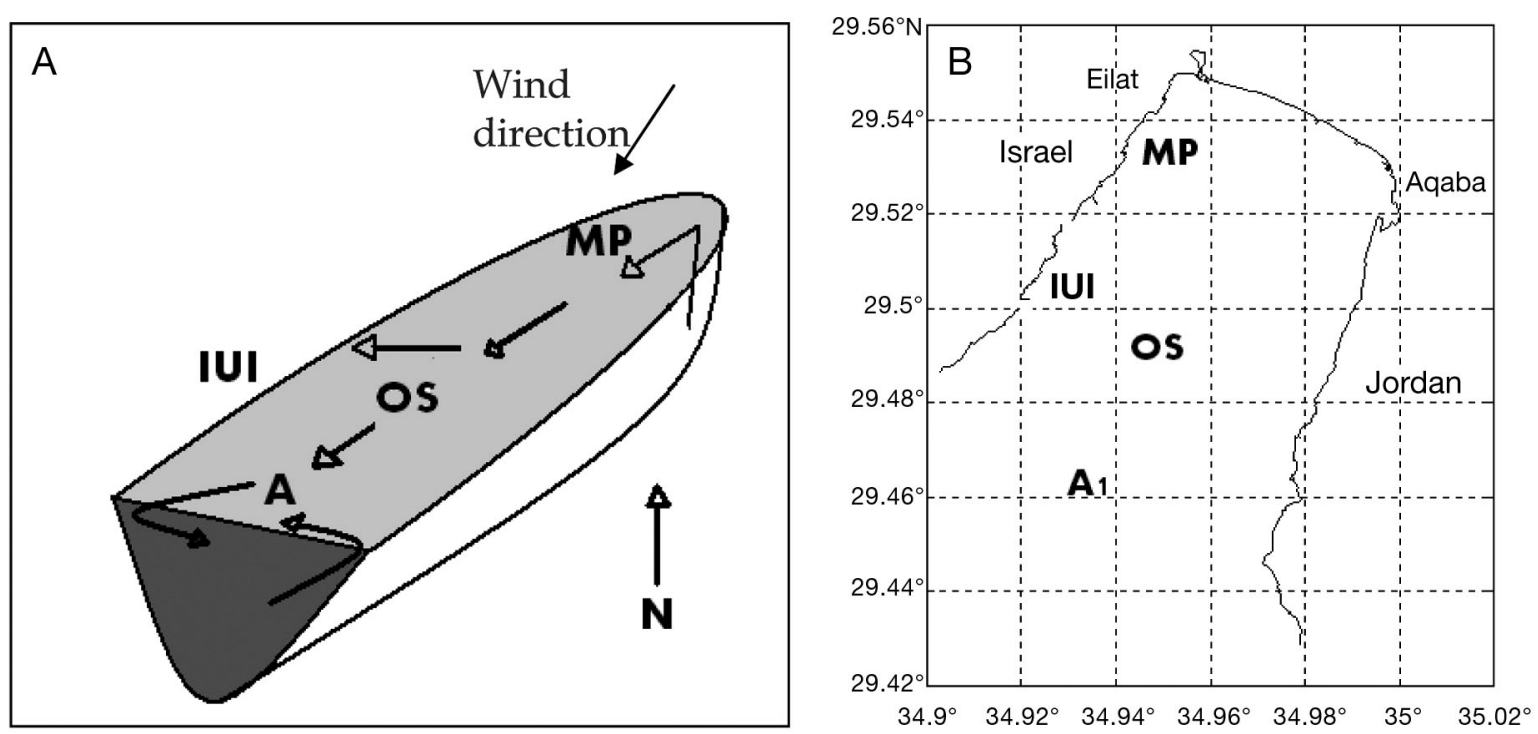

Fig. 1. (A) Schema of currents in the Gulf of Eilat in response to upwelling from northern coastal waters and downwelling from the west to the open sea deep water. (B) Map showing Stn $\mathrm{A}_{1}$ : $700 \mathrm{~m}$ bottom depth; Stn OS: 400 m; Stn MP: $30 \mathrm{~m}$, and IUI: incubation station, $150 \mathrm{~m}$ 
was calculated as the depth where $1 \%$ of $E_{\mathrm{d}} \mathrm{PAR}$ at $1 \mathrm{~m}$ was measured. The $E_{\mathrm{d}} \mathrm{PAR}$ values at $1 \mathrm{~m}$ were used instead of subsurface values since the latter were unusable due to high surface noise.

Nutrients. Nitrites and nitrates were analyzed using the colorimetric method described by Grasshoff et al. (1999) using a flow injection autoanalyzer (FIA, Lachat Instruments Model QuikChem 8000). The analysis was fully automated and peak areas were calibrated using standards prepared in 'low nutrient' filtered seawater (surface seawater sampled during the oligotrophic season in the Gulf of Aqaba) over a range of 0 to $5 \mathrm{\mu mol}^{-1}$. The precision of this method is $\pm 0.02 \mu \mathrm{mol} \mathrm{l}^{-1}$ for nitrites and $\pm 0.05 \mu_{\mathrm{mol}} \mathrm{l}^{-1}$ for nitrates.

Chl a. Chl a was estimated using natural fluorescence, i.e. $L_{\mathrm{u}}$ from the PRR-800 at $683 \mathrm{~nm}$. Chl a concentration $\left(\mathrm{mg} \mathrm{m}^{-3}\right)$ may be calculated from the natural fluorescence flux $\left(F_{\mathrm{f}}, \mathrm{nmol}\right.$ photon $\left.\mathrm{m}^{-3} \mathrm{~s}^{-1}\right)$, and the scalar irradiance $\left(E_{0}, \mu \mathrm{mol}\right.$ photon $\left.\mathrm{m}^{-2} \mathrm{~s}^{-1}\right)$, i.e. light flux from all directions:

$$
\mathrm{Chl}=\frac{F_{\mathrm{f}}}{{ }^{\circ} a_{\mathrm{C}} \mathrm{PAR} \times \phi_{\mathrm{f}} \times E_{\mathrm{o}} \mathrm{PAR}}
$$

Two important optical assumptions are used in this equation: ${ }^{\circ} a_{\mathrm{C}} \mathrm{PAR}$ is the chl $a$-specific absorption coefficient (absorption normalized to chl a concentration) and $\phi_{\mathrm{f}}$ is the quantum yield of fluorescence. These parameters are treated as constants in the software for the PRR-800, with respective values of $0.04 \mathrm{~m}^{2} \mathrm{mg}^{-1}$ and $0.045 \mu \mathrm{mol}$ photon fluoresced $\mathrm{m}^{-2} \mathrm{~s}^{-1}$ ( $\mu \mathrm{mol}$ photon absorbed $)^{-1} \mathrm{~cm}^{-2} \mathrm{~s}^{-1}$.

High-resolution measurements (4 to 6 times per day) resulted in a map of chl a values during the period before and after the study period. Data were plotted and interpolated using Ocean Data View (ODV) software (Schlitzer 2008). Since the chl a estimation algorithm is based on empirical constants (the chl a-specific absorption coefficient and the quantum yield of fluorescence), which were not derived specifically for our phytoplankton assemblages, we calibrated the estimated chl a against extracted chl a concentrations throughout 2008 (including profiles acquired during the present study), using 51 samples over a range of 0.01 to $1.14 \mathrm{mg} \mathrm{chl} \mathrm{a} \mathrm{m}^{-3}$. The calibration factor was calculated as chl $a\left(\mathrm{mg} \mathrm{m}^{-3}\right)=0.04 F_{\mathrm{f}} \mathrm{chl}-0.0192\left(\mathrm{R}^{2}=\right.$ 0.804).

Absorption spectra. In vivo phytoplankton absorption was measured using the filter-pad method (Mitchell et al. 2000) from the discrete samples collected at different depths. Amounts of 600 to $2000 \mathrm{ml}$ water were filtered onto $25 \mathrm{~mm} \mathrm{GF/F} \mathrm{(Whatman).} \mathrm{The}$ filters were placed in histoprep tissue capsules (Fisher Scientific) and stored at $-20^{\circ} \mathrm{C}$ until analysis 1 or $2 \mathrm{~d}$ later. The filters were scanned at 350 to $750 \mathrm{~nm}$ using a UV-visible spectrophotometer (Cary 50) to obtain total particulate optical density $\left(\mathrm{OD}_{\text {part }}\right)$. After pigment extraction with methanol, the filters were rescanned to obtain the optical density of the detrital material $\left(\mathrm{OD}_{\text {det }}\right)$. OD spectra were then corrected for pathlength amplification (Cleveland \& Weidemann 1993) and converted to absorption coefficient ( $\left.a_{\text {part } / \text { det }}\right)$ using:

$$
a_{\mathrm{x}}(\lambda)=\frac{2.303 \times \mathrm{OD}_{X}(\lambda)}{X}
$$

where the subscript $x$ denotes either particulate or detrital OD $(\lambda)$ and $X$ is the ratio of the filtered volume to the filter clearance area.

The absorption spectra were then corrected for residual scattering by subtracting the average over 748-752 nm from all measured spectra.

Phytoplankton absorption $\left(a_{\mathrm{ph}}\right)$ was calculated as the difference between total particulate $\left(a_{\text {part }}\right)$ and detrital absorption $\left(a_{\text {det }}\right)$ :

$$
a_{\mathrm{ph}}=a_{\text {part }}-a_{\text {det }}
$$

Phytoplankton enumeration. Samples $(100 \mathrm{ml})$ for phytoplankton enumeration were collected at $5 \mathrm{~m}$ depth and fixed with $100 \mu \mathrm{l}$ of a $25 \%$ glutaraldehyde solution. Samples were kept in low light and counted within $2 \mathrm{~d}$ of collection. For each sample, a $50 \mathrm{ml}$ subsample was counted using a phase contrast inverted microscope (Utermöhl 1958). Only phytoplankton cells with $>5 \mu \mathrm{m}$ diameter were identified (Tomas 1996). Phytoplankton biomass was estimated according to Edler (1979) and Menden-Deuer \& Lessard (2000).

Flow cytometry. Samples $(1.8 \mathrm{ml})$ for ultraphytoplankton were preserved with $1 \%$ glutaraldehyde (final concentration) and immediately frozen in liquid $\mathrm{N}$ and stored at $-80^{\circ} \mathrm{C}$. Before analysis, samples were quickly thawed at $37^{\circ} \mathrm{C}$ and counted in a flow cytometer (FACScalibur, Becton \& Dickinson). Phytoplankton samples were run at approximately $60 \mu \mathrm{min}^{-1}$ and 10000 events were acquired in log mode. We added yellow-green latex beads ( $0.93 \mu \mathrm{m}$, Polysciences) to each sample as an internal standard.

Silica deposition. Biogenic silica deposition was measured in natural phytoplankton assemblages using PDMPO (2-(4-pyridyl)-5-((4-(2-dimethylaminoethylaminocarbamoyl) methoxy)phenyl)oxazole) labeling following the modified protocol of Leblanc \& Hutchins (2005). On 1 to 3 April, fresh surface and deepwater samples were incubated with PDMPO (final concentration of $0.125 \mu \mathrm{M}$ ) using $250 \mathrm{ml}$ flasks. The samples were incubated in water tables with flowing seawater, and the tables were covered with window screening to reduce surface irradiance to $\sim 25 \%$. After a $24 \mathrm{~h}$ incubation, samples were brought to the laboratory and filtered through $2 \mu \mathrm{m}$ pore size polycarbonate filters (Osmonics, Poretics). Filters were rinsed with distilled water to eliminate any unbound PDMPO, placed on a drop of immersion oil on a glass slide and sealed under 
a glass cover with another drop of oil above the filter. A portion of cells actively depositing silica was counted immediately after filter preparation; PDMPO fluorescence was measured later. Epifluorescence microscopy coupled with digital image analysis was used for quantitative evaluation of PDMPO fluorescence $\left(F_{\mathrm{PDMPO}}\right)$, which was expressed in relative fluorescence units (RU) cell $^{-1}$ and calculated as described in Znachor \& Nedoma (2008). A paired 2-tailed Student's $t$-test was performed to examine differences in $\mathrm{Si}$ incorporation between surface populations and those at the deep chlorophyll maximum (DCM), with differences accepted as significant when $\mathrm{p}<0.05$.

Productivity (carbon assimilation). PP measurements were made using the ${ }^{14} \mathrm{C}$ uptake method described by Steeman-Nielsen (1952) and modified by Strickland \& Parsons (1968). Bottles containing $50 \mathrm{ml}$ samples of seawater were incubated in situ for $24 \mathrm{~h}$ at their original sampling depth after addition of $\sim 5 \mu \mathrm{Ci}$ of carrier-free $\mathrm{NaH}^{14} \mathrm{CO}_{3}$ (New England Nuclear). The mooring line with the incubation bottles was deployed $\sim 1 \mathrm{~km}$ offshore of the IUI (Fig. 1) at a bottom depth of 140 to $150 \mathrm{~m}$ before first light ( 04:00 h), and retrieved at the same time the following morning.

Upon retrieval, the incubation bottles were kept in a black box until filtration. The contents of the bottles were GF/F (Gelman) filtered with a Millipore glass filtration system under light vacuum $(15 \mathrm{~cm} \mathrm{Hg})$. These filters were then treated with $\mathrm{HCl}$ vapors to remove traces of inorganic carbon. The filters were placed in glass vials with $10 \mathrm{ml}$ Insta Gel (Packard) and counted in a liquid scintillation counter (Packard 3255) for 10 min each. Added activity was measured by sampling $50 \mu \mathrm{l}$ from each bottle and placing it on a GF/F filter soaked with $\mathrm{NaOH}$ to trap the $\mathrm{CO}_{2}$. The addedactivity samples were counted in the manner described above. The total inorganic carbon was determined from alkalinity (Strickland \& Parsons 1968). Productivity rates were then estimated using the JGOFS (Joint Global Ocean Flux Study) protocol (UNESCO 1994).

Estimated productivity $\left(F_{\mathrm{c}}-\mathbf{6 8 3}\right)$. Productivity estimated was estimated based on chlorophyll natural fluorescence at $683 \mathrm{~nm}$ wavelength, measured with an underwater spectro-radiometer (Biospherical PRR800). Natural fluorescence per volume $\left(F_{\mathrm{f}}\right)$ was derived from $L_{\mathrm{u}}$ in the chlorophyll emission spectrum. $F_{\mathrm{c}-683}$ productivity estimation uses the volume fluorescence $\left(F_{\mathrm{f}}, \mathrm{nmol}\right.$ photon $\left.\mathrm{m}^{-3} \mathrm{~s}^{-1}\right)$ and the scalar irradiance ( $E_{\mathrm{o}} \mathrm{PAR}, \mu \mathrm{mol}$ photon $\mathrm{m}^{-2} \mathrm{~s}^{-1}$ ) as well as photosynthetic parameters such as the maximal ratio of the quantum yields of photosynthesis to fluorescence ( $\phi_{\mathrm{rmax}} \mathrm{C}$ atom photon $^{-1}$ ) and the irradiance at which this ratio is $1 / 2$ of the maximum $\left(k_{\mathrm{cf}}, \mu \mathrm{mol}\right.$ photon $\left.\mathrm{m}^{-2} \mathrm{~s}^{-1} \mathrm{]}\right)$. These parameters were determined empirically and assigned as $\phi_{\mathrm{rmax}}=4 \mathrm{C}$ atom photon ${ }^{-1}$ and $k_{\mathrm{cf}}=133 \mu \mathrm{mol}$ photon $\mathrm{m}^{-2}$ (Kiefer et al. 1989, Chamberlin et al. 1990, Chamberlin \& Marra 1992).

$$
F_{\mathrm{c}}=F_{\mathrm{f}} \frac{k_{\mathrm{cf}} \phi_{\text {max }}}{k_{\mathrm{cf}}+E_{\mathrm{o}} \mathrm{PAR}}
$$

$F_{\mathrm{c}}$-683 estimations were made using PROFILER software (Biospherical Instruments). An onboard computer recorded the data online. Measurements were done from the surface down to $100 \mathrm{~m}$ at 13:00 to 14:00 h.

Regression of PP (estimated using in situ ${ }^{14} \mathrm{C}$ uptake) against estimated productivity based on fluorescence ( $F_{\mathrm{c}}$-683, measured in 3 profiles on different dates) showed a significant correlation: $Y\left(\mathrm{mg} \mathrm{C} \mathrm{m}^{-3} \mathrm{~d}^{-1}\right)=$ $1.469+0.592 X\left(F_{\mathrm{c}}-683\right.$ units $) ; \mathrm{r}^{2}=0.823 ; \mathrm{p}<0.0001 ; \mathrm{n}=$ 24 . Each profile was taken from 5 to $100 \mathrm{~m}$; no fluorescence readings were recorded in the upper $5 \mathrm{~m}$ because of the high ambient irradiance interference with readings from the PRR-800 reflectance radiometer.

Wind speed and direction data were obtained from the meteorological database maintained at the IUI.

\section{RESULTS}

Wind velocity changed dramatically throughout the study period and showed a diurnal variation of mainly high values during the day and low values at night. Wind speed was $\sim 3 \mathrm{~m} \mathrm{~s}^{-1}$ at midnight prior to sampling and increased to almost $10 \mathrm{~m} \mathrm{~s}^{-1}$ the next day (2 April 2008) (Fig. 2B). The changes in wind speed also affected the temperature profiles, which displayed a sharp decrease (from 21.7 to $21.4^{\circ} \mathrm{C}$ in $15 \mathrm{~h}$ ) at the surface (Fig. 2A). The thermocline, which was at $5 \mathrm{~m}$ on 1 April at $13: 40 \mathrm{~h}$, moved to a depth of $\sim 35 \mathrm{~m}$ the following day (Fig. 2B). Temperature profiles during 20 March to 7 May 2008 showed significant changes in temperature during the storm event (Fig. 3). Following the strong wind event on 1 April, water transparency declined; $K_{\mathrm{d}(\mathrm{PAR})}$ increased from 0.076 to $0.090 \mathrm{~m}^{-1}$ and $Z_{\text {eu }}$ increased from $60 \mathrm{~m}$ to $45 \mathrm{~m}$, which is shallower than typically observed at this time of the year (Iluz 1997). $Z_{\text {eu }}$ continued to decrease for $4 \mathrm{~d}$ showing high diel variability, and increased once again by 6 April (Fig. 4).

$\mathrm{Chl}$ a concentration was low and showed the typical vertical variation for the study area. The deep chlorophyll maximum (DCM) was at $30 \mathrm{~m}$ on 31 March, with a maximum value of $\sim 1.5 \mathrm{\mu g} \mathrm{l}^{-1}$, but deepened during the remainder of the observation period, with declining chl a concentrations that reached a minimum on 8 April (Fig. 5).

\section{Phytoplankton community structure}

Throughout the experiment, picophytoplankton $\left(<5 \mu \mathrm{m}\right.$ ) increased from 25 to $50 \mu \mathrm{g} \mathrm{Cl}^{-1}$ (see Bar Zeev 

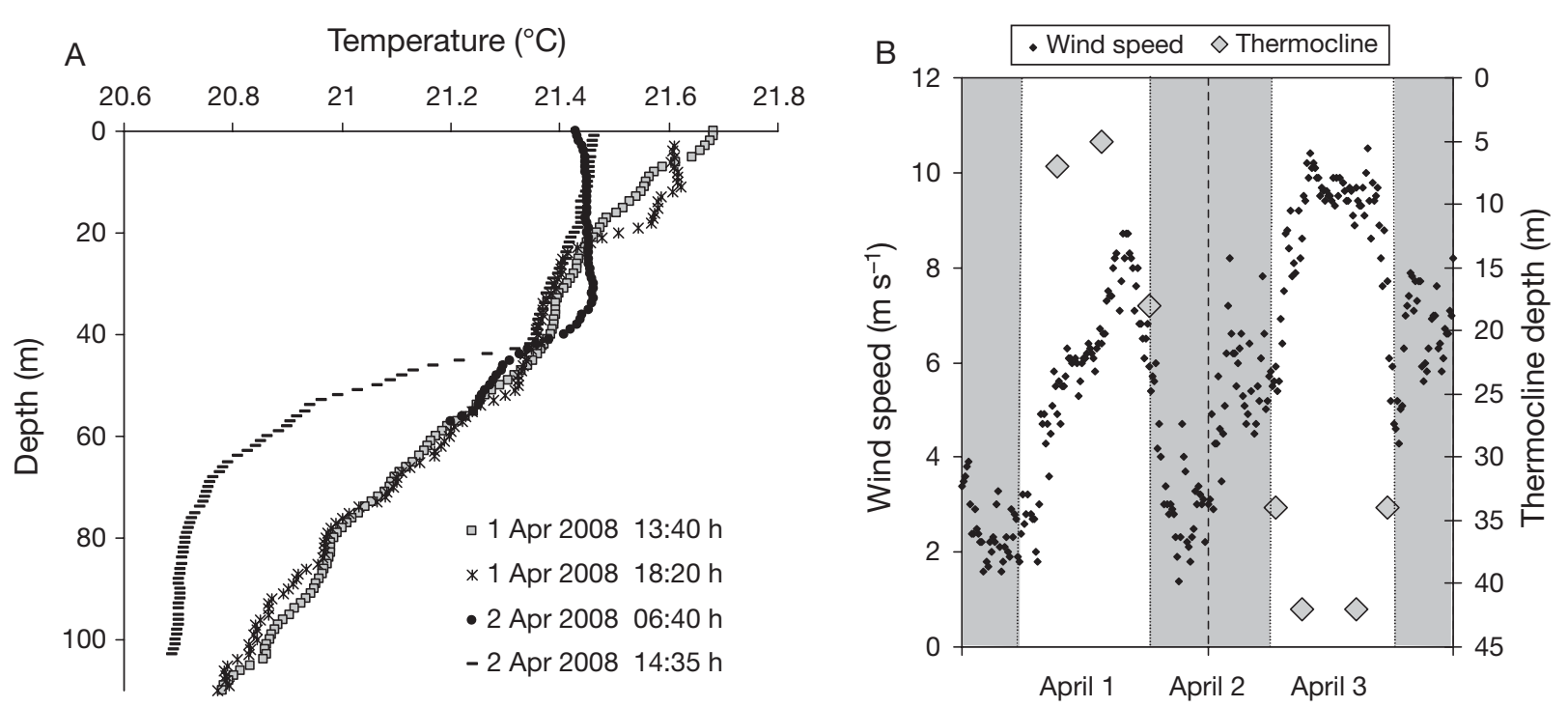

Fig. 2. (A) Temperature profiles and (B) wind speed during 1 to 2 April 2008. Grey shading in (B) indicates dark periods

et al. 2009). The $>5 \mu \mathrm{m}$ fraction of the phytoplankton population was dominated by diatoms, which represented up to $99 \%$ of the abundance and $90 \%$ of the total biomass of the nanoplankton. Diatoms were at their lowest abundance and biomass on 1 April $\left(6 \times 10^{3}\right.$

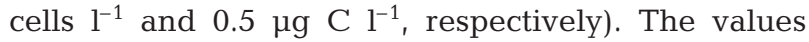
increased again sharply on 3 April to $228 \times 10^{3}$ cells $^{-1}$ (abundance) and $20 \mu \mathrm{g} \mathrm{Cl}^{-1}$ (biomass) (Fig. 4A). From 4 April, diatom abundances decreased to values recorded prior to the strong wind event of 1 April. A centric diatom, Chaetoceros cfr. compressus, dominated the phytoplankton population during the sampling period, representing up to $84 \%$ of the cells identified in the samples and up to $64 \%$ of the total biomass. Other chain-forming centric diatoms (e.g. Leptocylindrus danicus, Eucampia cornuta, and Chaetoceros curvisetus) accounted for a maximum of $28 \%$ of the remaining phytoplankton biomass.

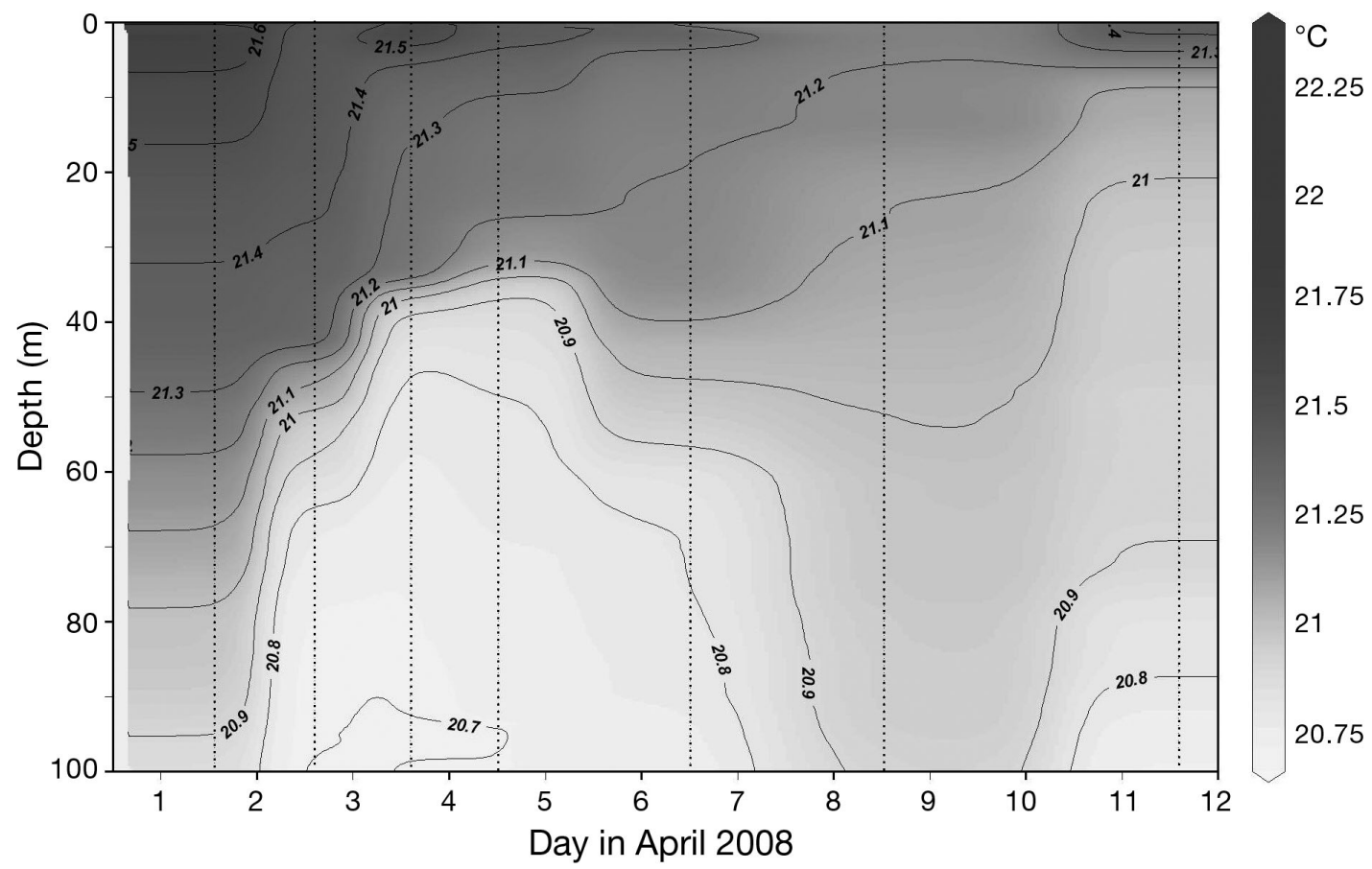

Fig. 3. Temperature profiles during 1 to 12 April 2008. Vertical dashed lines indicate measurement days which occurred in parallel to the storm event, showing significant changes in temperature 


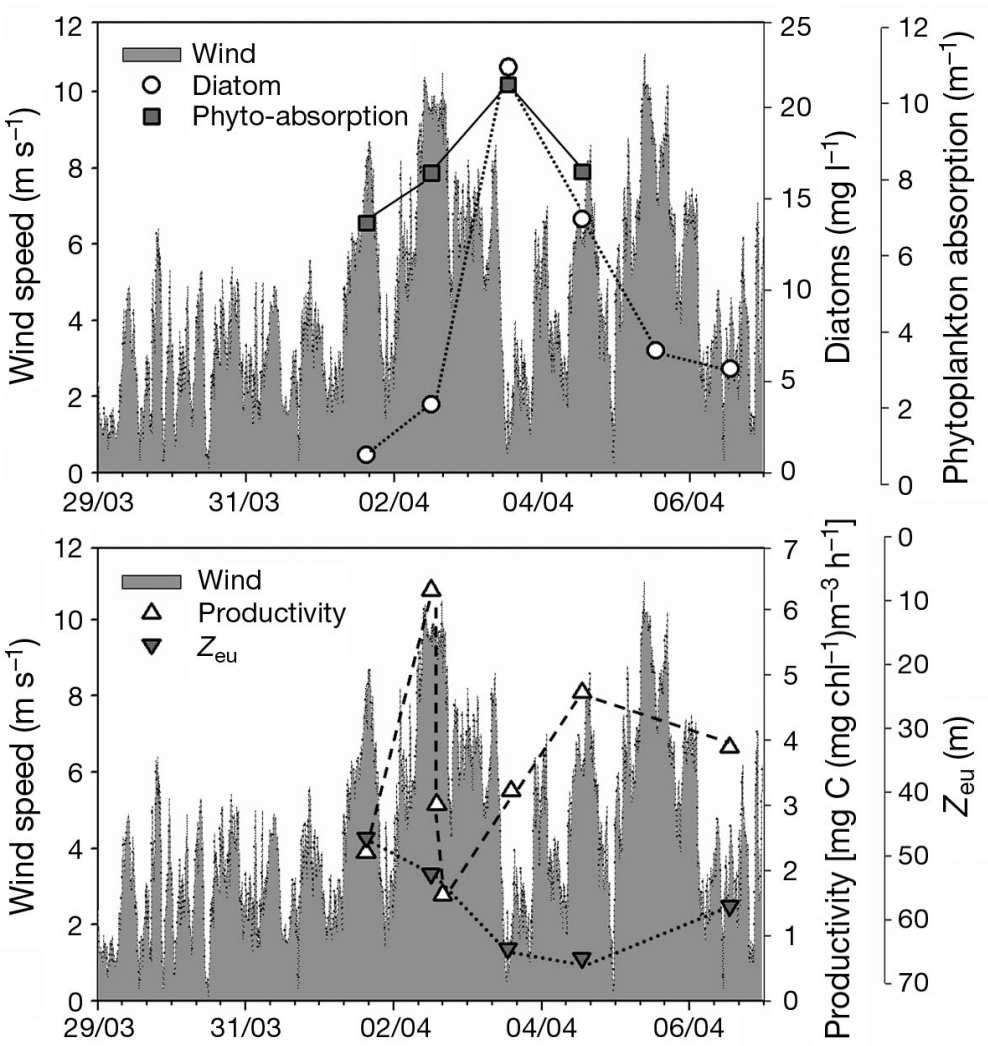

Fig. 4. (A) Wind speed ( $\mathrm{m} \mathrm{s}^{-1}$ ) during 28 March to 9 April 2008, diatom biomass $\left(\mu \mathrm{g} \mathrm{C}^{-1}\right.$ ) at $5 \mathrm{~m}$ depth from 1 to 6 April 2008, and phytoplankton absorption of photosynthetically active radiation (PAR) $\left(\mathrm{m}^{-1}\right)$. (B) Wind speed $\left(\mathrm{m} \mathrm{s}^{-1}\right)$ during 28 March to 9 April 2008, estimated productivity $\left(F_{\mathrm{C}^{-}}\right.$ 683; $\mathrm{mg} \mathrm{C}[\mathrm{mg} \mathrm{chl} \mathrm{a}]^{-1} \mathrm{~m}^{-3} \mathrm{~h}^{-1}$ ), and euphotic depth $Z_{\text {eu }}$ (average of 3 to 5 measurements $\mathrm{d}^{-1}, y$-axis reversed)

\section{Phytoplankton absorption}

Phytoplankton pigment absorption changed temporally. Phytoplankton absorption at $435 \mathrm{~nm}, a_{\mathrm{ph}}(435)$, increased from $0.045 \mathrm{~m}^{-1}$ on 1 April to $0.060 \mathrm{~m}^{-1}$ on 2 April and $0.062 \mathrm{~m}^{-1}$ on 3 April, and then decreased to $0.043 \mathrm{~m}^{-1}$ on 4 April. The $a_{\mathrm{ph}}(675)$ also varied accordingly. Phytoplankton pigment absorption at PAR (400-700 nm) showed a similar trend as $a_{\mathrm{ph}}(675), a_{\mathrm{ph}}(435)$, and the diatom biomass (Fig. 4A).

\section{Primary productivity}

Within $1 \mathrm{~d}$, productivity at $20 \mathrm{~m}$ depth increased from $15 \mathrm{mg} \mathrm{C} \mathrm{m}{ }^{-3} \mathrm{~d}^{-1}$ at Stn OS (1 April 2008) to $35 \mathrm{mg} \mathrm{C} \mathrm{m}{ }^{-3} \mathrm{~d}^{-1}$ at $\operatorname{Stn} \mathrm{A}_{1}(2$ April 2008) (Fig. 6). The daily integrated PP in the coastal Stn MP on 1 April was $1141 \mu \mathrm{g}$ $\mathrm{C} \mathrm{m}^{-2}$. We obtained similar and even higher values (1330 $\mu \mathrm{g} \mathrm{C} \mathrm{m}{ }^{-2}$ ) at Stn $\mathrm{A}_{1}$ (located $10 \mathrm{~km}$ from Stn MP) on 2 April.

\section{Silica deposition}

Biogenic silica deposition was measured using PDMPO fluorescence to compare the growth rates of the dominant diatom

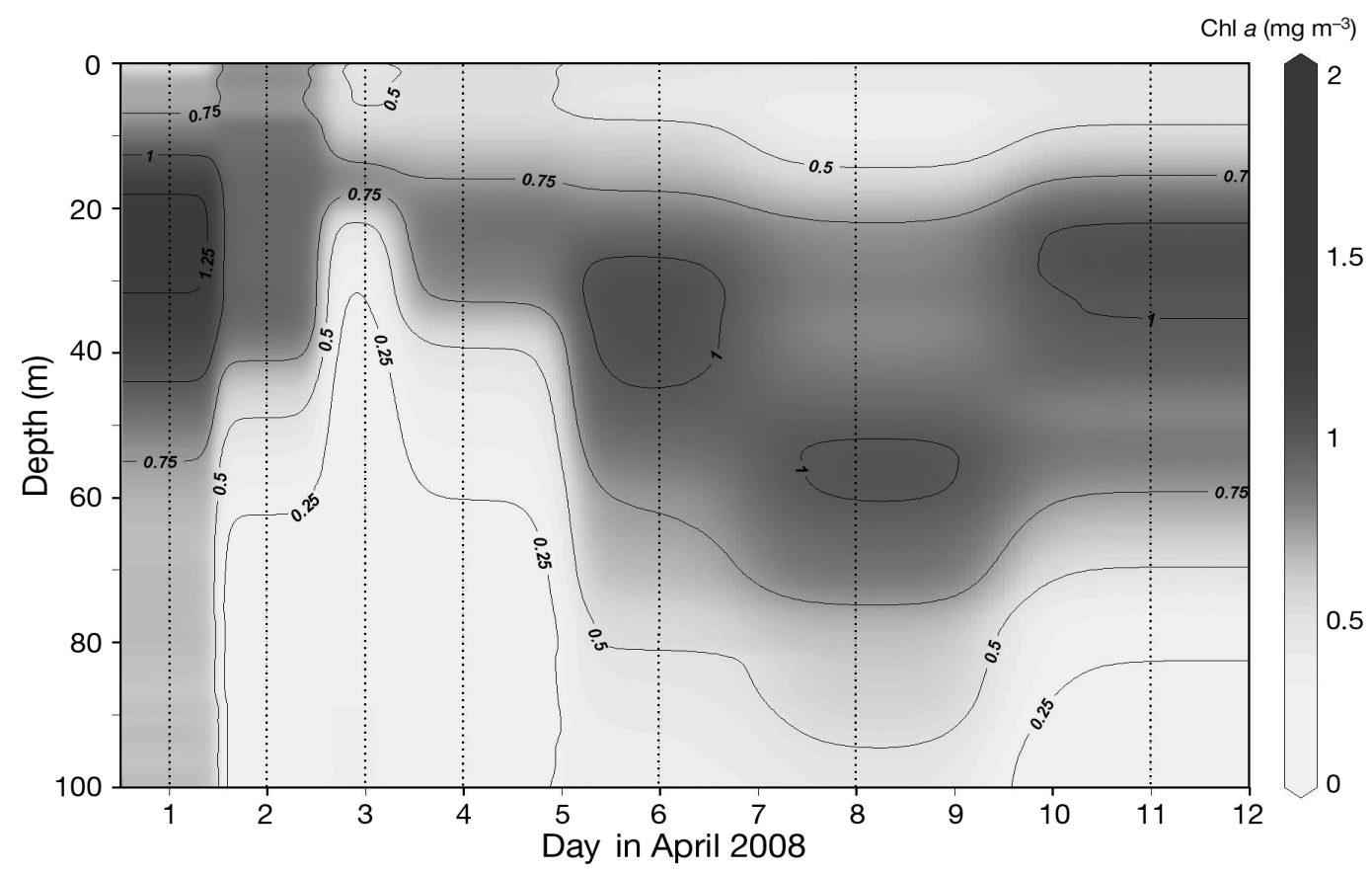

Fig. 5. Chl a concentration $\left(\mathrm{mg} \mathrm{m}^{-3}\right)$ at various depths, showing changes in the deep chlorophyll maximum (DCM) during 1 to 12 April 2008. Vertical dashed lines indicate measurement days that occurred concurrently with the storm event 
Chaetoceros spp. during the study period. Due to low abundance of the other diatom species, their contribution to $\mathrm{Si}$ deposition could not be measured. In general, Si deposition of Chaetoceros was significantly higher at the DCM depth than at the surface $(t=2.9, \mathrm{p}<0.01)$. On 1 April, low abundance of Chaetoceros spp. concurred with low silica deposition rates $\left(F_{\mathrm{PDMPO}}=0.07 \mathrm{RU}\right.$ cell $^{-1}$ ). During a peak in the Chaetoceros bloom on 2 April, Si deposition rates markedly increased ( $F_{\mathrm{PDMPO}}$ $=0.38 \mathrm{RU}$ cell $^{-1}$ ) and most of the population was involved in $\mathrm{Si}$ deposition at both the surface and the

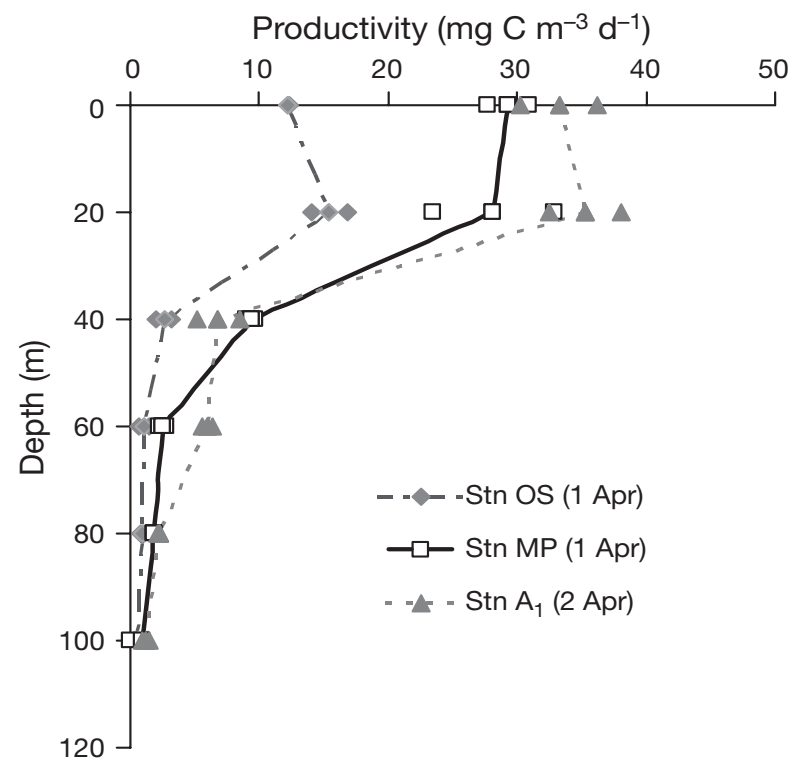

Fig. 6. In situ primary production profiles at Stns MP (Military Port, 1 April), OS (open sea, 1 April), and $A_{1}$ (2 April). The incubation at $\mathrm{Stn} \mathrm{A}_{1}$ was on 2 April 2008
DCM, indicating high growth rates. However, the day after the bloom, Chaetoceros growth rates dropped down to previous values, most likely due to nutrient depletion. On 1 April, concentrations of dissolved inorganic nitrogen (DIN) (nitrite and nitrate) ranged between 0.01 and $0.02 \mu \mathrm{M} \mathrm{N}$, while it increased abruptly in near-surface waters on 2 April, reaching concentrations of 0.08 to $0.1 \mu \mathrm{M} \mathrm{N}$. The day after the bloom, DIN levels decreased to 0.01 to $0.03 \mu \mathrm{M} \mathrm{N}$.

\section{DISCUSSION}

Daily PP and chl a concentration during the study period were the highest ever recorded in the Gulf of

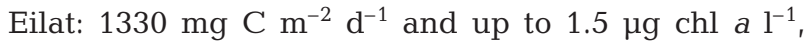
respectively, which is almost $3 \times$ higher than average chl $a$ values at this time of year in this area. Our results suggest an abrupt increase in mixing. The data show a sharp increase in the biomass of diatoms and in the rates of PP over a short time. Wind direction was from the coast towards the open Gulf, and upwelling was induced. PP is usually higher in the northern and coastal stations than in the open Gulf (Iluz 1997), but in the experiment reported here, we observed that on 1 April 2008 and the following day, the rates at Stn $A_{1}$ (10 km from MP) increased to a level similar to that of the coastal Stn MP. The changes were limited to the upper $40 \mathrm{~m}$ (Fig. 6), with no significant increase in either biomass or productivity below this depth. We assume that the increased wind speed induced the transfer of a coastal water mass from the northern shore towards the open sea. This water is more nutrient rich than that of the open sea, and thus supports
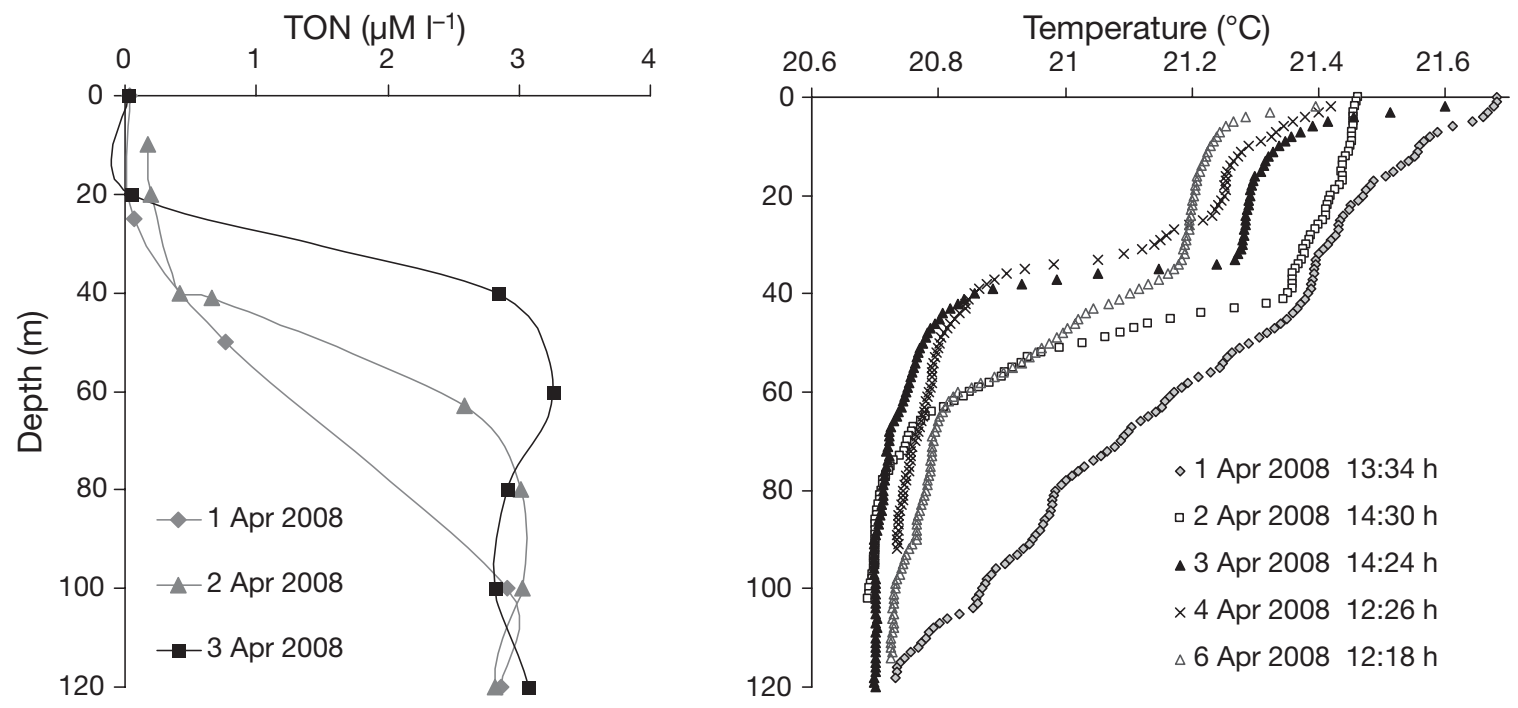

Fig. 7. (A) Profiles of total organic nitrogen (TON) on 1 to 3 April 2008, and (B) temperature on 1 to 6 April 2008, showing mixing from the surface and mixing of upwelled water at depth 
the higher productivity near the northshore. This movement of the water mass is confirmed by temperature profiles (Figs. 2, 3, 7). In the period from 1 to 3 April, total organic nitrogen (TON) and temperature profiles revealed 2 current components: upwelling of colder and nutrient rich water from deep layers in the north towards the surface waters of the open sea, coupled with lateral downwelling of warm, surface waters that sink along the western shore of the Gulf and flow as a deep current towards the center of the Gulf (Fig. 1A) (Labiosa et al. 2003). Diatom abundance and biomass increased sharply over 2 d from 1 to 3 April, which accounts for the increased Si deposition by these cells and the concomitant depletion of $\mathrm{Si}$ in the water. The growth rates of the dominant diatom Chaetoceros doubled within $2 \mathrm{~d}$ and dropped the following day to pre-bloom values, probably due to nutrient exhaustion. As expected, the increase in PP preceded that of the biomass, which was phase-shifted by $1 \mathrm{~d}$ in relation to PP. Picophytoplankton are usually the main producers in the Gulf of Eilat and contribute $>90 \%$ to PP (Lindell \& Post 1995); these phytoplankters probably responded rapidly to nutrient enrichment. Diatoms have a slower response than picophytoplankton, which explains the observed lag between the PP peak and maximum diatom cell density (Fig. 4).

During the reported period, the sky was cloud-free; therefore, insulation may be excluded as a factor that might have induced the changes in phytoplankton density and vertical distribution, which were attested by changes in chl a concentration (Fig. 5). On the other hand, wind speed changed and correlated well with water column optical properties (Fig. 4B).

In the Gulf of Eilat, the main seasonal ecological patterns are driven by mixing that usually takes place between February and April and which is characterized by deep convective mixing of the northern Gulf, which may extend down to hundreds of meters and even to the very bottom (Wolf-Vecht et al. 1992, Genin et al. 1995). Nutrients upwelled from depth and from coastal waters enrich the euphotic zone and increase $\mathrm{PP}$. There are exceptional events that can raise $\mathrm{PP}$, such as a high degree of mixing resulting from a particularly cold winter, as happened at the end of the winter in 1992, when the highest total daily PP rates ever recorded in the region were measured (738 mg C $\mathrm{m}^{-2} \mathrm{~d}^{-1}$ ). (During 1989-1997, the multi-annual average productivity rate was $\sim 200 \mathrm{mg} \mathrm{C} \mathrm{m} \mathrm{m}^{-2}$; Iluz 1991, 1997). Winters in the Gulf of Eilat are exceptionally cold, resulting in very intense deep mixing (>750 m) and increased nutrient injection from deep waters of the Gulf. As a result, a strong spring bloom develops at the onset of stratification (Gordon et al. 1994, Genin et al. 1995). Additional exceptional but local events are floods of the Shlomo River, as occurred in 1993 and which increased productivity to $604 \mathrm{mg} \mathrm{C} \mathrm{m}^{-2} \mathrm{~d}^{-1}$ (Iluz 1997).

The northern edge of the Gulf of Eilat borders the relatively populated areas of the cities of Aqaba and Eilat, where anthropogenic pollutant sources such as fish farms and sewage may produce impacts on the marine environment. However, the influence of these pollution sources seems, so far, to be of a slow and gradual nature. In contrast, the event that we report here was abrupt and prominent in its effects on the biology of the water. As the situation observed was apparently wind-driven, it is expected that it may occur repeatedly in the Gulf. Northern wind events with speeds exceeding $9 \mathrm{~m} \mathrm{~s}^{-1}$ occurred $\sim 10 \times$ between 1 April 2007 and 1 May 2008, each lasting for at least 2 to $3 \mathrm{~d}$. We do not know if these events had the same effects as those recorded in this report, and it is obvious that such observations should be repeated over several seasons to allow reliable estimation of their impacts on annual PP.

It is noteworthy that routine ocean monitoring programs in which PP is measured once or twice a month are likely to miss their brief but significant spikes, leading to underestimation of seasonal and annual PP values. If these values are significant for total biomass, we should consider them in our calculations, as well as study their impact on the storage and flow of energy through marine food webs and ecosystems.

Our recommendation is that, whenever possible, the sampling frequency for PP measurements should be increased using PP fluorescence calculations based on the $F_{C}-683$ method described here. Otherwise, where different automated systems tracking chlorophyll are installed, closely spaced PP measurements should be conducted when any sudden increase in pigment concentration is detected, in order to include otherwise undetected peaks. Such measurements would significantly increase and improve our annual estimates, and provide better databases for ecosystem models. Furthermore, such peaks are likely to trigger microbial and zooplankton peaks that may be missed or remain inexplicable. The advantage of the $F_{\mathrm{c}}-683$ method is its high resolution and ease of operation that allow several measurements of depth profiles throughout the day. Such work would be nearly impossible with ${ }^{14} \mathrm{C}$ incubations.

Acknowledgements. We thank the Batsheva de Rothschild Foundation, Bar-Ilan University, the Moshe Shilo Center for Marine Biogeochemistry, and the staff of the Interuniversity Institute for funding and logistic support. We also thank the NATO Foundation (Sfp-981883) for funding part of the research of D.I. and G.D.; and Z. Dubinsky, Y. Yacobi and E. Bar Zeev for contributions to this paper. Attendance at the workshop by V.M. was partially supported by a grant from the Universidad de Chile, and R.A. was funded by BELSPO BEL- 
COLOUR-2 project (SR/00/104). This study was conducted during the 8th International Workshop of the Group for Aquatic Primary Productivity (GAP) and the Batsheva de Rothschild Seminar on Gross and Net Primary Productivity held at the Interuniversity Institute for Marine Sciences, Eilat, Israel in April 2008.

\section{LITERATURE CITED}

Bar Zeev E, Berman-Frank I, Stambler N, Vázquez Domínguez E and others (2009) Transparent exopolymer particles (TEP) link phytoplankton and bacterial production in the Gulf of Aqaba. Aquat Microb Ecol 56:217-225

Behrenfeld MJ, Randerson JT, McClain CR, Feldman GC and others (2001). Biospheric primary production during an ENSO transition. Science 291:2594-2597

Benitez-Nelson C (2000) The biogeochemical cycling of phosphorus in marine systems. Earth Sci Rev 51:109-135

> Chamberlin WS, Marra J (1992) Estimation of photosynthetic rate from measurements of natural fluorescence: analysis of the effects of light and temperature. Deep-Sea Res 39:1695-1706

Chamberlin WS, Booth CR, Kiefer DA, Morrow JH, Murphy RC (1990) Evidence for a simple relationship between natural fluorescence, photosynthesis, and chlorophyll in the sea. Deep-Sea Res 37:951-973

> Chase Z, Paytan A, Johnson KS, Street J, Chen Y (2006) Input and cycling of iron in the Gulf of Aqaba, Red Sea. Global Biogeochem Cycles 20:GB3017, doi:10.1029/ 2005GB002646

> Chen Y, Mills S, Street J, Golan D, Post A, Jacobson M, Pay$\tan A$ (2007) Estimates of atmospheric dry deposition and associated input of nutrients to Gulf of Aqaba seawater. J Geophys Res 112:D04309, doi:10.1029/2006JD007858

Chen Y, Paytan A, Chase Z, Measures C and others (2008) Sources and fluxes of atmospheric trace elements to the Gulf of Aqaba, Red Sea. J Plankton Res 113:1-13

Cleveland JS, Weidemann AD (1993) Quantifying absorption by aquatic particles: a multiple scattering correction for glass-fiber filters. Limnol Oceanogr 38:1321-1327

Codispoti LA (1989) Phosphorus vs. nitrogen limitations of new and export production. In: Berger WH, Smetacek VS, Wefer G (eds) Productivity of the ocean: present and past. J Wiley \& Sons, Chichester, p 377-394

D'Elia CE, Sanders JG, Boynton WR (1986) Nutrient enrichment studies in a coastal plain estuary: phytoplankton growth in large scale, continuous cultures. Can J Fish Aquat Sci 43:397-406

Delesalle B, Pichon M, Frankignoulle M, Gattuso JP (1993) Effects of a cyclone on coral reef phytoplankton biomass, primary production and composition (Moorea Island, French Polynesia). J Plankton Res 15:1413-1423

Duce RA, LaRoche J, Altieri K, Arrigo K and others (2008) Impacts of atmospheric anthropogenic nitrogen on the open ocean. Science 320:893-897

Dugdale RC (1967) Nutrient limitation in the seas: dynamics, identification, and significance. Limnol Oceanogr 12:685-695

Edler L (ed) (1979) Recommendations for marine biological studies in the Baltic Sea: phytoplankton and chlorophyll. Baltic Mar Biol 5:1-38

Eppley RW, Peterson BJ (1979) Particulate organic matter flux and planktonic new production in the deep ocean. Nature 282:677-680

Field CB, Behrenfeld MJ, Randerson JT, Falkowski P (1998) Primary production of the biosphere: integrating terrestrial and oceanic components. Science 281:237-240
Filippelli GM, Delaney ML (1996) Phosphorus geochemistry of equatorial Pacific sediments. Geochim Cosmochim Acta 60:1479-1495

Follmi KB (1996) The phosphorus cycle, phosphogenesis and marine phosphate-rich deposits. Earth Sci Rev 40:55-124

> Genin A, Lazar B, Brener S (1995) Vertical mixing and coral death in the Red Sea following the eruption of Mount Pinatubo. Nature 377:507-510

Gordon N, Angel DL, Neori A, Kress N, Kimor B (1994) Heterotrophic dinoflagellates with symbiotic cyanobacteria and nitrogen limitation in the Gulf of Aqaba. Mar Ecol Prog Ser 107:83-88

Grasshoff K, Kremling K, Ehrhardt M (eds) (1999) Methods of seawater analysis, 3rd edn. Wiley-VCH, Weinheim

Hans P (1997) Coastal eutrophication and harmful algal blooms: importance of atmospheric deposition and groundwater as 'new' nitrogen and other nutrient sources. Limnol Oceanogr 42:1154-1165

Iluz D (1991) Primary production of phytoplankton in the northern Gulf of Eilat, Red Sea. MSc thesis, Bar-Ilan University, Ramat-Gan (in Hebrew with English abstract)

Iluz D (1997) The light field, phytoplankton pigmentation and productivity in the Gulf of Eilat. PhD thesis, Bar-Ilan University, Ramat-Gan (in Hebrew with English abstract)

Kiefer DA, Chamberlin WS, Booth CR (1989) Natural fluorescence of chlorophyll a: relationship to photosynthesis and chlorophyll concentration in the western South Pacific gyre. Limnol Oceanogr 34:868-881

Labiosa RG, Arrigo KR, Genin A, Monismith G, van Dijken G (2003) The interplay between upwelling and deep convective mixing in determining the seasonal phytoplankton dynamics in the Gulf of Aqaba: evidence from SeaWiFS and MODIS. Limnol Oceanogr 48:2355-2368

Leblanc K, Hutchins DA (2005) New applications of a biogenic silica deposition fluorophore in the study of oceanic diatoms. Limnol Oceanogr Methods 3:462-476

Lindell D, Post AF (1995) Ultraphytoplankton succession is triggered by deep winter mixing in the Gulf of Aqaba (Eilat), Red Sea. Limnol Oceanogr 40:1130-1141

Mackey KRM, Labiosa RG, Street JH, Paytan A (2006) Nitrogen and phosphorus co-limit growth and control community composition and taxon specific nutrient status in the Gulf of Aqaba, Red Sea. EOS Trans Am Geophys Union 86:52

Mackey KRM, Labiosa RG, Calhoun M, Street JH, Post AF, Paytan A (2007) Phosphorus availability, phytoplankton community dynamics, and taxon-specific phosphorus status in the Gulf of Aqaba, Red Sea. Limnol Oceanogr 52:873-885

McGillicuddy Jr DJ, Laurence AA, Bates NR, Bibby T and others (2007) Eddy/wind interactions stimulate extraordinary mid-ocean plankton blooms. Science 316:1021-1026

Menden-Deuer S, Lessard EJ (2000) Carbon to volume relationship for dinoflagellates, diatoms and other protist plankton. Limnol Oceanogr 45:569-579

Mitchell BG, Bricaud A, Carder K, Cleveland J and others (2000) Determination of spectral absorption coefficients of particles, dissolved material and phytoplankton for discrete water samples. In: Fargion GS, Mueller JL (eds) Ocean optics protocols for satellite ocean color sensor validation, Rev 2. NASA/TM-2000-209966, NASA Goddard Space Flight Center, Greenbelt, MD, p $125-153$

Nixon SW (1986) Nutrient dynamics and the productivity of marine coastal waters. In: Halwagy R, Clayton D, Behbehani M (eds) Marine environment and pollution. Alden Press, Oxford, p 97-115 
Redfield AC (1958) The biological control of chemical factors in the environment. Am Sci 46:205-221

Ryther JH, Dunstan WM (1971) Nitrogen, phosphorus and eutrophication in the coastal marine environment. Science 171:1008-1 112 .

Scanlan DJ, Wilson WH (1999) Application of molecular techniques to addressing the role of $\mathrm{P}$ as a key effector in marine ecosystems. Hydrobiology 401:149-175

Schlitzer R (2008) Ocean data view. http://odv.awi.de

Steeman-Nielsen E (1952) Measurements of production of organic matter in the sea by means of carbon-14. Nature 267:684-685

Strickland JDH, Parsons TR (1968) A practical handbook of seawater analysis. Bull Fish Res Bd Can 167:1-311

Tomas CR (1996) Identifying marine phytoplankton. Academic Press, San Diego, CA

Editorial responsibility: Hugh MacIntyre,

Dauphin Island, Alabama, USA
Tyrrell $\mathrm{T}$ (1999) The relative influences of nitrogen and phosphorus on oceanic primary production. Nature 400: $525-531$

UNESCO (1994) Protocols for the joint global ocean flux study (JGOFS) core measurements. IOC manuals and guides 29. UNESCO, Paris, p 170

Utermöhl H (1958) Zur Vervollkomnung der quantitativen Phytoplankton-Methodik. Mitt Int Ver Theor Angew Limnol 9:1-38

Wolf-Vecht A, Paldor N, Brenner N (1992) Hydrographic indications of advection/convection effects in the Gulf of Eilat. Deep-Sea Res 39:1393-1401

Znachor P, Nedoma J (2008) Application of the PDMPO technique in studying silica deposition in natural populations of Fragilaria crotonensis (Bacillariophyceae) at different depths in a eutrophic reservoir. J Phycol. 44:518-525

Submitted: December 9, 2008; Accepted: May 6, 2009 Proofs received from author(s): June 22, 2009 